\title{
Citing 'Whatever' Authority: The Ethics of Quotation in the Work of Giorgio Agamben
}

\author{
Colby Dickinson \\ Loyola University Chicago, cdickinson1@luc.edu
}

Follow this and additional works at: https://ecommons.luc.edu/theology_facpubs

Part of the Religious Thought, Theology and Philosophy of Religion Commons

Author Manuscript

This is a pre-publication author manuscript of the final, published article.

\section{Recommended Citation}

Dickinson, Colby. Citing 'Whatever' Authority: The Ethics of Quotation in the Work of Giorgio Agamben. Educational Philosophy and Theory, , : , 2014. Retrieved from Loyola eCommons, Theology: Faculty Publications and Other Works, http://dx.doi.org/10.1080/00131857.2013.786868

This Article is brought to you for free and open access by the Faculty Publications and Other Works by Department at Loyola eCommons. It has been accepted for inclusion in Theology: Faculty Publications and Other Works by an authorized administrator of Loyola eCommons. For more information, please contact ecommons@luc.edu. cc) (i) $\Theta$

This work is licensed under a Creative Commons Attribution-Noncommercial-No Derivative Works 3.0 License. (c) 2013 Philosophy of Education Society of Australasia. 


\title{
Citing 'whatever' authority: The ethics of quotation in the work of Giorgio Agamben
}

\author{
Colby Dickinson \\ Loyola University Chicago
}

\begin{abstract}
This paper seeks to lay out an analysis of Giorgio Agamben's central claims with regard to the formation of a theory of citationality. By juxtaposing Walter Benjamin's theory of citations alongside his more recent, critical engagements with the western theological tradition, Agamben sets himself the goal of redefining ethics along Levinasian lines in order to arrive at a respect for the face of 'whatever' being before us, the true source toward which all citations point.
\end{abstract}

\section{Keywords: Giorgio Agamben, Walter Benjamin, citations, citationality, authority}

\section{Introduction}

Put simply, no matter how they are performed, citations are references made to an original source (their origin), made in order to bolster an argument or claim to legitimacy. For this reason, citations are also inherently contentious, whether presented as such or not. For example, there may be a discrepancy between the citation and the source, or a source may be used incorrectly—taken 'out of context'—or the use of a source might simply appear as 'dated' or uncritically appropriated, having been discredited since the advent of its publication. Perhaps the biggest offender among these might be the use of a citation with no immediate relevance to the context of a present argument, one which was simply used to convey a sense of authority to the claims being made, as if simply the mention of a particularly revered source were enough to dispel any attempts to make a claim to the contrary.

In recent memory, the investigation of the usage of citations - their role and function in society in general - has given rise to further deepened theories of 'citationality' that seek to explore everything from the performability and reproducibility of the 'signature' (Derrida) to the manner in which even gender could be said to cite previous social performances of its kind (Butler 1993). The import of these claims, if considered on the whole, is that citations are explicit acts of social, cultural, political and even religious representation. They are seldom posited neutrally - their careful selection often speaks volumes enough 
already — and they are often the difference between safeguarding a common practical sense of intelligibility (for most) and providing a much sought after emancipation (for some). A quick scan of one's frequently used sources is often enough therefore to loosely identify one's particular ideological leanings. Yet, as any 'reputable' or 'respectable' academic society will testify, it is the use of these citations, and the traditions they inspire, which grants a certain intelligibility to our discourses. Without them, we would otherwise seemingly run the risk of being incomprehensible, or-perhaps worse—of simply not being taken seriously. Negotiating the middle ground between these two positions, as I will argue in what follows, is the difficult territory within an educational setting that must become more transparent.

Beginning with a theory of citations in the work of the late-modern German literary critic Walter Benjamin, before turning to its subsequent elaboration and acquired ethical dimensions in the work of Giorgio Agamben, I seek here to demonstrate something essential to the nature of citations and the role(s) they play in culture today, both within and beyond their literary and academic contexts. This is in many ways a task of exposing the tactics of a practice so common to academic contexts that it often goes unnoticed: claims of authority and legitimation in general are posited and contested through the citations we invoke, whether we recognize this fact or not. In so many words, a more fully developed theory of citationality, as I am here attempting to sketch, might enable us to better grasp not only the undisclosed role of citations in academic contexts today, but also the aporia (and hence impossibility) of an authority's supposed legitimation, its 'ungroundedness' as it were. The inability to ever fully ground one's authority over time, that is, to reign 'legitimately' as sovereign in any sense (and this is the political question that Agamben has pursued in a variety of contexts), is illustrated by the often ambiguous and ultimately unjustifiable usage of citations.

Following from this, Agamben's depiction of citationality can be seen as a heavy contestation of the western cultural tradition, a creative re-reading 'against the grain' which attempts to undo the obfuscations of our most normative claims and their accompanying frequent citations. By conducting my inquiry thus, I intend to show how, over and beyond the theological—Agamben's most recent and choice discipline in this respect - the ultimate source sought by all citations, again whether social, cultural, political or religious, according to Agamben, is the singular nature of the face before us, the 'whatever' face that calls us to a relationship bound by love. Within this rather Levinasian sounding proposition, Agamben works quickly toward an examination of the ethical dimensions of citations. By opening our thought to an ethics 'beyond representation', then, Agamben seeks to challenge our standardized conceptualizations of ethics, in order to offer us a completely new manner by which to view the use of citations today. 


\section{Cultural transmission as the art of myth}

I begin with Walter Benjamin, whose work has been heavily influential upon the Englishspeaking world in the last few decades (see, among others, Caygill; Weber). Beyond the seemingly strange and unusual topics he often chose as his subject matter (e.g. children's toys and books, photography, shopping arcades, major European urban landscapes, etc.), Benjamin was in no small measure fascinated with the art of collecting. It was something that he often directly wrote about, from the associations made while unpacking his own library (Benjamin 1999a, 2:pp. 486-93) to his more studied reflections upon the Marxist art historian Eduard Fuchs, 'Collector and Historian' (Benjamin 2002, 3:pp. 260-85). Collections were, for Benjamin, more than bourgeois indulgences; they were an open door to the past that likewise contained the potential to reassign values within a contemporary context. They were for him the most 'profane' manifestations of a 'nearness' to the past, something that could almost conjure a sacred air with their very presence. They were, in fact, that which binds us to the past better than anything else in our modern world could (Benjamin 1999b, pp. 205).

In the face of traditions which were, and still are, dissolving, the collector becomes the individual who exhibits this reality of relations best through a transfiguration of objects removed from their original, historical context. This is an act which Agamben, who is also Benjamin's Italian translator and editor, will describe as, 'suddenly depriving them both of their use value and of the ethical-social significance with which tradition had endowed them' (Agamben 1999, p. 105). Henceforth, collections seemingly float through existence, removed from any worldly economy and severed from any meaningful use within a particular, traditional society. Hence the quasi-mystical character they exude simply by existing, a quality many a modern museum patron might also attest to. It should further be stated that Agamben's relevance here is no minor matter for further developing Benjamin's theory of collecting.

Over the past several years, Agamben's popularity among scholars working within a wide array of fields has itself grown quite quickly (see, among others, Durantaye; Mills; Zartaloudis). And, I would note, it is in his (re)articulations of Benjamin's theory of cultural transmission that we are privy to the political dimensions present in any 'renewal' of a given tradition and its accompanying authority. This is indeed a profound connection that can be gathered under the mark of 'citationality', as we shall soon see.

At this point, however, and within the context of collecting, Agamben considers the course of Benjamin's analysis as illustrating a 'revolutionary' disjuncture in history (cf. Fritsch). As he puts it, the collector is something of a 'revolutionary' figure, since, for both, '[...] the new can appear only through the destruction of the old. And it is certainly not an accident that the great collector figures flourish precisely in times of break from tradition and exaltation of renewal [...] (Agamben 1999, p. 105). This 
development is in sharp contrast, we are told, to a 'traditional society' wherein '[...] neither the quotation nor the collection is conceivable, since it is not possible to break at any point the links of the chain of tradition by which the transmission of the past takes place' (Agamben 1999, p. 105). Like the nostalgia for former national contexts which have since collapsed and which subsequently drive interest in collecting goods and memorabilia from such periods (as, for example, with the 'Ostalgie' some people display for the former East Germany), a fondness for these historical items can only derive its worth from a radical rupture within our representations of history and its traditional contextual moorings (i.e. national, ideological, etc).

As Agamben will further assert, the phenomenon of collecting in the modern era is inseparable from our cultural perceptions of art. Indeed, understanding the relation of the two, collecting and art, can aid our comprehension of the ethos in which we are situated. Our present age, Agamben considers, is one wherein the art collections housed in public museums quickly find their mirror image in private houses that are turned into quasi-museums. This lack of a genuine of the art within one's daily life experience is symbolized by the place of the museum in society today, or, as he puts it, 'The impossibility of using has its emblematic place in the Museum' (Agamben 2007. p. 84). This trend for him represents not only a seismic shift in the cultural relevance of art, but also the impossibility of an authentic experience being present through art, not to mention the impossibility of an actual use being attached to many objects within someone's own home. It registers an 'impossibility of use' that one faces when confronted with the reality of 'things' themselves. As such, our world is immersed within a state of constantly expanding collections, something he terms 'the museification of our world'. This is the reality in which 'One by one, the spiritual potentialities that defined people's lives—art, religion, philosophy, the idea of nature, even politics-have docilely withdrawn into the Museum' (Agamben 2007, p. 84). And it is this 'enclosure' of the space of the 'museum' which has almost paradoxically expanded to encompass most of our living space. 'In this sense, the Museum can coincide with an entire city [...] a region [...] and even a group of individuals [...] But more generally, everything today can become a Museum, because this term simply designates the exhibition of an impossibility of using, of dwelling, of experiencing' (Agamben 2007, p. 84). As a quasi-sacred zone, the boundaries of the museum come to proclaim the definitive eradication of (daily, practical) use of the objects that are part and parcel of humanity itself. These objects, having been 'museified', are now rendered useless to humanity, captured within the domain of an aesthetic which cannot bring them (mythically) back to 'life' (as something 'useable'). How an ethical (or religious) experience, or any experience at all for that matter, is possible within the modern era thus remains tentative at best.

Instead, as he will elaborate in another context, art now only maintains its ability to identify itself with the destruction of tradition, with the intransmissibility that is at the origin of 'the experience of 
shock' (Agamben 1999, p. 106). This is a process which, in the last half of the previous century, had quickly taken to accelerating the forces of disruption, producing a 'shock' value intended to invoke a radical disruption with history itself. As each new stage of art seemingly renders the mediums and modalities of previous eras insufficient, outdated, and surpassed, we are inundated by the relics or items now intended only for collections, not for actual use. Art itself becomes only that which is to be collected, with its past, symbolic role consequently being further lessened over time. In effect, the 'latest' and 'most contemporary' art, pushed to its most extreme form, will in fact only serve the purpose of preventing traditional forms of cultural transmission and translatability from taking place.

Politics becomes, in this context, re-defined as the space where meaningful symbolic utterance is continuously narrowed by these (artistic) processes, because it is precisely these processes that define the public sphere of intelligibility. As he puts it, 'The reproduction of the dissolution of transmissibility in the experience of shock becomes, then, the last possible source of meaning and value for things themselves, and art becomes the last tie connecting man to his past' (Agamben 1999, p. 107). In turn, this permanently present existence of art isolates traditional forms of both meaning and value, threatening to render many peoples and cultures as symbolically obsolete. The present subject of cultural transmission becomes as such ever more alienated, indeed even solipsistic. In this sense, 'The survival of the past in the imponderable instant of aesthetic epiphany is, in the final analysis, the alienation effected by the work of art, and this alienation is in its turn nothing other than the measure of the destruction of its transmissibility, that is, of tradition' (Agamben 1999, p. 107).

With this advent of the unprecedented destruction of tradition, what becomes clear is that—while this is no longer the case-culture once was inseparable from its transmission. While 'pre-modern', it was united as a single entity within a given context, defining traditional societies as communities with no gap between their past and their present, that is, between their culture and its transmission. The recording of history had not yet acquired its modern focus upon the dichotomy of continuity and rupture. From this pre-modern perspective, values, whether ethical, religious or aesthetic, had no meaning outside of this indissoluble bond between the act of transmission and the thing being transmitted. In many ways, modern attempts to formulate an ethics based on communitarian values are still founded on the possibility of this connection, a linkage which Agamben wholeheartedly denies as a genuine possibility for our age. In contradistinction to this state of 'traditional' affairs, the 'interruption of tradition [...] opens an era in which no link is possible between old and new, if not the infinite accumulation of the old in a sort of monstrous archive or the alienation effected by the very means that is supposed to help with the transmission of the old' (Agamben 1999, p. 108). This state gives rise, then, to an 'accumulated culture', as he puts it, that yet presses forward through time without meaning, and which seemingly functions only 
to reveal our suspension in a groundless void of existence. It is an accumulation that gathers itself under the sign of 'the collection', the debris lying in piles among us.

The deep resonance of this theme with the 'angel of history' as depicted by Benjamin is purposefully re-asserted by Agamben in this context. For Benjamin, the angel, as the illustrative figure of his final great work 'On the Concept of History', becomes symbolic of the melancholic engagement with the past, with its thrust toward the future and with the impossibility of transmitting the past to the present, or that which seemingly most needs to be retained from all of history. As Benjamin describes the angel,

His face is turned toward the past. Where a chain of events appears before $u s$, he sees one single catastrophe, which keeps piling wreckage upon wreckage and hurls it at his feet. The angel would like to stay, awaken the dead, and make whole what has been smashed. But a storm is blowing from Paradise and has got caught in his wings; it is so strong that the angel can no longer close them. This storm drives him irresistibly into the future, to which his back is turned, while the pile of debris before him grows toward the sky. What we call progress is this storm. (Benjamin 2003, p. 392)

For Agamben, this image captures the ragged edge of the situation humanity now faces: our complete encasement within the aesthetic (i.e. the modern 'museification' of the world), and the impossibility of our truly ever reaching the domain of the mythical-theological, despite our desire to ascend to it. As he comments on this state of affairs, 'The past that the angel of history is no longer able to comprehend reconstitutes its form in front of the angel or art; but this form is the alienated image in which the past finds its truth again only on condition of negating it, and knowledge of the new is possible only in the nontruth of the old' (Agamben 1999, p. 110). Again, the rupture is affirmed as the very way in which art re-constitutes itself in the present.

The best that humanity can now achieve is a sort of 'suspended' living, one that neither touches the core of our reality as human-being nor fabricates a solution to the deadlock between the past and the present. Everything in fact seems bound for a course of destruction and the accompanying debris which seems to dissolve any chance for redemption. This is a problem as theological as it is historical, though the difference between them is not always clear, and its implications stretch even further than this, as I will suggest. The only reality to be grasped in this world, and by this score, is one of an inherent alienation of the subject who struggles to comprehend and grasp the symbols at hand, that is, to (aesthetically) give order to them in some sense, all the while ultimately failing to achieve the traditional (mythological-theological) meaning once ascribed to life (that which had once guaranteed its meaning) (cf. Benjamin 199b, 'Convolute N'). Hence, Agamben's commentary on Benjamin's most fundamental historical image:

The redemption that the angel of art offers to the past, summoning it to appear outside its real context on the day of aesthetic Last Judgment, is, then, nothing other than its death (or rather, its inability to die) in the museum of aesthetics. And the angel's melancholy is the consciousness 
that he has adopted alienation as his world; it is the nostalgia of a reality that he can possess only by making it unreal. (Agamben 1999, p. 110)

The integrity of experience once present to us in its fullness, as undivided and in some sense 'pure', is now forever separated from itself, causing each possession (as part of a collection) to remain in an ethereal state only, again suspended from actual use. Each concrete reality exists consequently as ultimately inexperienceable. Mirroring his comments elsewhere on the poetic (Agamben 1991, p. 74ff; 1993a, p. 15ff; 1993b, p. xvii), Agamben here depicts the contemporary aesthetic project as one that is fundamentally intertwined with the plight of the modern autonomous subject in that this subject must, in a sense, utilize art in order to inhabit its world, even if it is an 'unreal' world in many respects.

As such, aesthetics comes to replace tradition in the contemporary world, uniting the past we cannot fully grasp with the present wherein we are continuously having to re-create ourselves. By doing so, however, and as an astute observer might suspect, contemporary aesthetics actually begins to praise its discontinuity with the past, offering this rupture itself as valuable to the processes of forming a modern subjectivity. As Agamben frames it, 'By destroying the transmissibility of the past, aesthetics recuperates it negatively and makes intransmissibility a value in itself in the image of aesthetic beauty, in this way opening for man a space between past and future in which he can found his action and his knowledge' (Agamben 1999, p. 110). In which, he will later state directly, humanity can reign sovereign (Agamben 2004). Under these conditions, the survival of culture is itself lodged within the modern alienation of art, and its intransmissability is a sign of its perpetual need for re-creation, something perhaps not unfamiliar to an advanced capitalist economy or a pop art/advertising mentality. It is also in many ways the prime exemplar of the human condition, the state of humanity in which we must ceaselessly articulate ourselves in order to posit itself as 'real' (human beings) over and against the animality of our nature (cf. Agamben 2004).

Aesthetics today thus performs a two-fold act of extreme significance which we can now note: it eradicates the distance between the object of history and its transmission into the present, and, as it accomplishes this act, it inches closer toward the boundary of what was once the mythical-traditional. This occurs yet with one important distinction still remaining between the 'traditional society' and our own: art '[...] although it can reach the threshold of myth, it cannot cross it' (Agamben 1999, p. 114). In this frustration, and by refusing to force a conceptual bridge to be constructed between them, humanity is capable of comprehending, perhaps for the first time, the true nature of its (art-ificial) situatedness in the world:

If man could appropriate his historical condition, and if, seeing through the illusion of the storm that perennially pushes him along the infinite rail of linear time, he could exit his paradoxical situation, he would at the same time gain access to the total knowledge capable of giving life a new cosmogony and to turn history into myth. But art alone cannot do this, since it is precisely in 
order to reconcile the historical conflict between past and future that it has emancipated itself

from myth and linked itself to history. (Agamben 1999, p. 114)

It is this modern 'aesthetic' deadlock which allows humanity to grasp its dwelling within the world most acutely. In this fashion, art touches the border of what was traditionally the domain of the mythicreligious. Despite this proximity, however, it cannot cross over into 'becoming myth' as it were. Art stands alone as it were and religion in its traditional forms is determined to be hollow. The symbols which once most sustained the continuity between traditions and their people (the 'political theologies' that gave rise to elaborate and rich religious landscapes) are now suspended amidst a quest for (aesthetic) meaning that is prevented from continuing itself. Art, in the end, enacts nothing more profound than the revelation of our sense of alienation in the world.

Echoing one of Agamben's basic re-iterations in this context, and as he here reads Kafka very closely, we might be able to see how redemption for the modern subject, waits on the other side, though, as Kafka said, it is 'not for us' (Agamben 2005a, pp. 56-7). Beyond this, however, it is more than just our understanding of religion or myth that is deeply altered by such insights, for from the traditional space occupied by the theological flows our very relationship to language itself, to all writing then, and certainly (perhaps above all else) to those tirelessly working to lend some sense of authority or meaning to their work through the citations they invoke (see Agamben 2010a).

\section{Citing the Messiah}

This refusal to endorse redemption as a concept 'for us' moderns is something which Agamben takes significantly to heart. It is a situation for him that is embraceable through the fact that Kafka's genius, as Benjamin had previously noted, is that he was able to sacrifice 'truth for the sake of transmissibility' (Agamben 1999, p. 114; cf. Benjamin 1973, p. 763). This fact is what prods Agamben to cite Kafka as the writer who 'most coherently' displays this interruption of the linear time of history. It is an interruption that art tries to re-appropriate and bridge this gap by juxtaposing alongside it 'the paradoxical image of a state of history in which the fundamental event of the human condition is perpetually taking place; the continuum of linear time is interrupted, but does not create an opening beyond itself' (Agamben 1999, p. 113). It is also a purely immanent consideration of how humanity constantly engages with its own identity, framed by the intransmissability of the past and so also perpetually in need of re-establishing itself. This is a condition, we might add, that is never fully resolved because humanity is not able to properly unify its past with its present. 
For Benjamin, who developed a form of 'dialectical materialism' precisely to address such a split in humanity's 'origins', the figure of the messiah (whether conceivable as an historical person, or as an image from the past) was crucial to fulfilling history and recuperating, in some sense at least, our humanity. A messiah was the only figure who could bridge the gap between art and myth, restoring humanity's fundamental symbols to their proper use. It is the messiah as messenger who 'reveals' the linguistic fact of our being to us, as the use of the concept logos to identify the messiah in Christianity will make more than clear. This is the message that concerns the nature of the medium itself, and thus, for Agamben, announces the significance of language in establishing 'humanity' as such. ${ }^{1}$ Stating the existence of language therefore $i s$ the fundamental human trajectory that all of our human endeavors point toward, with religion maintaining simply a privileged position, according to Agamben, in this regard (Agamben 2000a, 'The Idea of Language'). This 'revelation' will even induce him to construct an image of a messenger similar to Benjamin's, a messenger who is the long-awaited messianic figure who brings this knowledge down to us, and would have it circulate among us.

This 'messenger', moreover, is the figure of the messiah, a religious historical figure whom Agamben depicts as involved in 'revealing' the origin of language as nothing more than the task of transmission itself. With this characterization, he is able to portray the messianic figure historically as one who restores humanity to its own 'infancy', a place of openness and pure potentiality, the only true act of redemption possible for a humanity otherwise bent on securing its own actuality (as a bid for sovereignty) (cf. Agamben 1993a). It is only this messianic movement-which is an apparent regression, if you will - that finally engages in acts of profanation in order to allow humanity to appropriate an historical space for itself, to remove things from their 'museified' (quasi-sacred) state and return them to their intended use. His radical rereading of Saint Paul, in the midst of a continuous contemporary revival of philosophical views on Pauline literature, also reveals as much (see Agamben 2005a). In a nutshell, these are the threads which unite all of Agamben's varied works. Indeed, this is a linkage between threads that is only further certified for Agamben by the indissociable, though undisclosed, bond between Benjamin and Saint Paul, a forceful structural connection made in order to depict the 'weak force' of messianic power working within history. As Agamben puts it himself, '[...] this orientation toward the past characteristic of Benjamin's messianism finds its canonic moment in Paul' (Agamben 2005a, p. 144). This is, of course, certainly not a claim which all Benjamin scholars must find convincing, but it is one that lies central to Agamben's securing of his own philosophical integrity.

\footnotetext{
1 'Since the goal is already present and thus no path exists that could lead there, only the perennially late stubbornness of a messenger whose message is nothing other than the task of transmission can give back to man, who has lost his ability to appropriate his historical space, the concrete space of his action and knowledge' (Agamben 1999, p. 114).
} 
It is a difficult connection to prove conclusively, especially since it potentially involves the controversial use of what Benjamin referred to as a 'citation without citation', something which sounds dangerously close to plagiarism in its most literal form. It is also, however, that which Agamben detects at work in Benjamin's conceptualization of history as an indebtedness to Pauline thought that Benjamin himself had to efface in order to remain loyal to the logic of citationality, as I will now try to explain. According to Agamben, this was a logic which bound Benjamin to approach the truth of Paul's propositions, as it were, without relying upon the authority of the source, an attempt perhaps to subvert the traditional (over)reliance upon citations as legitimations of one's position and certainly an attempt to avoid 'being sovereign' in some sense. The stress of the contemporary 'fracture of being', its radicality, and its crisis today, however, is what presses Agamben to work toward an 'unveiling' of sources in this regard. As he puts it, 'Whatever the case may be, there is no reason to doubt that these two fundamental messianic texts of our tradition, separated by almost two thousand years, both written in a situation of radical crisis, form a constellation whose time of legibility has finally come today [...]' (Agamben 2005a, p. 145). This is a constellation upon which Agamben, for his part, will heavily rely.

By aligning Benjamin's theory of citationality within a Pauline framework with his own earlier work on art and history (which we have just seen), Agamben is able to work toward a definition of the citation that parallels his comments on art as the 'secret meeting place' between the past and the present. Accordingly, pulling citations (as messianic images) from the past in order to destroy (otherwise violent and imposing) representations within the present: this, and only this, is the way toward undermining the traditional notions of authority that have dominated our world under the banner of 'sovereignty' for centuries, something which we are today perhaps only just now beginning to discern in some sense (Agamben 2005a, p. 139). ${ }^{2}$ This leads Agamben to rearticulate Benjamin's essential point: 'When it is truly redeemed and truly saved, humanity is therefore in possession of its past. But for humanity to be in possession of it, Benjamin says, is for it to be able to cite it' (Agamben 2000a, pp 151-2). The citation, as such, appears consequently as the key to restoring the modern alienated subject, though we still need to flush out the details of what such an illumination may involve.

This desire for citations as a reworking of the past is what, undoubtedly, lies center-stage within Benjamin's grandiose Arcades Project, a piecemeal of associations and quotations never formally finalized but which contained the fragments of his entire corpus. In it were the citations and assorted reflections which characterized the culmination of his thoughts on a materialist historiography as it was concerned with the collision of tradition and catastrophe, with a 'tradition that is catastrophe' (Benjamin

\footnotetext{
${ }^{2}$ Likewise, this seems to be the source of Agamben's involvement with German legal theorist Carl Schmitt and his Homo Sacer project, for the link between citation and authority is one which reveals the powers at work in our world as much as the means toward subverting them (cf. Agamben 1998; Agamben 2005b).
} 
1999b, p. 473). As Agamben, for his part, unpacks Benjamin's 'theory of citation', he begins to negotiate the journey between the poles of destruction and creation, catastrophe and tradition, until the line between them begins to blur. Citation destroys, to be sure, as it rips words from their originary context: 'To write history thus means to cite history. It belongs to the concept of citation, however, that the historical object in each case is torn from its context' (Benjamin 1999b, p. 476) - but it is also, at the same time, an act of transfiguration worked in coordination perhaps with the power of justice, as his celebrated theses on the concept of history make abundantly clear. These 'destructive forces' of liberation are housed in the act of citation itself, setting Benjamin's project at a great distance from any historicist effort to 'eternalize' the past or fix the narrative of 'History' once and for all. In Benjamin's depiction, rather, any redemption of the past is necessarily the way in which to fulfill it, and therefore closer to the means of discarding certain readings of it. It is a 'return to origins' that liberates them from their place within a given canonical representation of history without necessarily involving an historical, locatable origin as such. Hence, as Agamben will describe it, 'The return to the origin that is at issue here thus in no way signifies the reconstruction of something as it once was, the reintegration of something into an origin understood as a real and eternal figure of its truth' (Agamben 2000a, p. 152).

And this is the truth of origins that Agamben detects at work in Benjamin's study, for 'According to Benjamin, by contrast — and the radicality of his thought lies here- to redeem the past is not to restore its true dignity, to transmit it anew as an inheritance for future generations' (Agamben 2000a, p. 153). A true redemption of the past can only bring matters to a close, not perpetuate them further, as conceivable on something like the Day of Judgment: 'For Benjamin, what is at issue is an interruption of tradition in which the past is fulfilled and thereby brought to its end once and for all. For humanity as for the individual human, to redeem the past is to put an end to it, to cast upon it a gaze that fulfills it' (Agamben 2000a, p. 153). This is a task both to 'shake off the past and bring it into the hands of humanity', what Agamben unhesitatingly calls an 'unusual' task (Agamben 2000a, p. 153). 'Unusual' perhaps because it appears to do away with historical narrativizing altogether-perhaps another, more alienating dis-junction of the modern subject. And yet citations are not just messianic fulfillments (in a theological sense) but also the unsurprising upending of historical representations themselves, a living-in-the-present which cannot be manipulated for canonical-ideological or religious ends. For Agamben, at least, bringing 'dialectics to a standstill' is the first fundamental act taken toward ending political and cultural representations as a whole, the completed task of a profanation of the quasi-sacred museum pieces and the start of a community still yet to come (Agamben 1993c).

As we have already seen for Benjamin, the real issue at stake within modernity was one concerning the 'transmissibility of culture' and the increasingly complex impasses which any attempt at 
transmission would inevitably encounter. Following Agamben's formulation of this context, we are able to see how

The particular power of quotations arises, according to Benjamin, not from their ability to transmit that past and allow the reader to relive it but, on the contrary, from their capacity to "make a clean sweep, to expel from the context, to destroy." Alienating by force a fragment of the past from its historical context, the quotation at once makes it lose its character of authentic testimony and invests it with an alienating power that constitutes its unmistakable aggressive force. (Agamben 1999, p.104)

And this reality of the citation, in some sense at least, is what first confronts the reader of Benjamin's Arcades Project, a project dedicated to ('aggressively') re-defining the scope of how the $19^{\text {th }}$ Century is historically perceived. At the same time, however, the stakes within Benjamin's project were far greater, attempting to do nothing less than completely (re)conceive the relationship between history and authority, as I have been indicating throughout this essay. Authority, from his view, is only maintained through time by traversing over its own historical context, that is, by being torn as a citation from its context, registering itself for an instant in the present (its 'now-time' or Jetztzeit of the dialectical image 'at a standstill') (Benjamin 1999b, p. 473). A fuller significance of this passage is now made legible to us as we stand to contextualize these remarks within the scope of Agamben's own claims against the linkage of citation and authority. As Agamben puts it quite pointedly, 'Benjamin, who for his entire life pursued the idea of writing a work made up exclusively of quotations, had understood that the authority invoked by the quotation is founded precisely on the destruction of the authority that is attributed to a certain text by its situation in the history of culture' (Agamben 1999, p. 104).

Authority is established, in Benjamin's eyes, by superseding (destroying) all previous claims to authority, and thereby exposing the processes of sovereign power that function within the act of citation. What Benjamin does to these processes, however, and through his own use of citations, is not simply a perpetuation of this cycle. He is rather determined to upend its functioning and to provide an alternate reading of history-its liberating (messianic) weak force. For Benjamin then, as Agamben puts it,

Its truth content is a function of the uniqueness of its appearance, alienated from its living context in what Benjamin, in his "Theses on the Philosophy of History," defines as "une citation à l'ordre du jour' ("a quotation on the order of the day") on the day of the Last Judgment. The past can only be fixed in the image that appears once and for all in the instant of its alienation, just as a memory appears suddenly, as in a flash, in a moment of danger. (Agamben 1999, pp. 104-5)

In many ways, the appearance of the past image (Benjamin's messianic image), torn forever from its historically-situated context, was an appearance of authority from outside of whatever 'authority' had been constituted as sovereign. This is an appearance of an authority on the level of citations that could only be read as a contestation of whatever 'authority' posited itself as such in the present. An almost paradoxical definition of authority ('paradoxical' because only an authority from outside of what is 
presently considered as 'authoritative' can be said to arise from history), it provides a unique commentary on an earlier aporia of the grounding of authority which Agamben had been attempting to work out in relation to citationality. This aporia becomes manifest precisely in what he calls the "vicious circle of authority and citation'. Specifically, it is an aporia wherein 'authority is the source of the citation but the citation is the source of authority', a state which then 'renders impossible the birth of real authority in the modern world (or, more exactly, only renders possible its “authoritarian" counterfeit) [...]' (Agamben 1993b, p. 74). This is consequently to reveal a force of citation which is deliberately, and often, employed within the various social, cultural, political and religious domains in order to achieve hegemonic ends. ${ }^{3}$ It is also the staple tactic employed in all academic and educational contexts though with assuredly less understanding of the reasons as to why this citational reality is exercised as such.

What all of this is leading us toward is the question of whether citations from the past register themselves as an authority that is capable of disrupting the present 'authoritative' structuring of cultural legibility, or whether they in turn legitimate such an order. Either way, citationality should be conceived as being among the ranks of a political decisionism in some sense, deftly choosing from among the ruins of history for its own canonical (and so always to some extent ideological, or religious) representations. As such, new 'less violent' forms of citation might develop in the future, while the 'more violent' forms are slowly eradicated from general acceptance. ${ }^{4}$ Yet, things might also not be so simple. According to Agamben's reading of Benjamin, this often repeated formulation does not fully embrace the radicality of Pauline, messianic thinking. Indeed, the complexity of citationality may in fact come to reflect the complex (mis)readings of the coming of an historical messiah, ones we have on record, such as the tension evident between the expectations of a political messiah (who would redefine political representations, as with the Maccabean revolt, etc) and a messiah who comes to end political representation itself (for Agamben, this is Paul's Christ) (see Agamben 2005a).

For Agamben, the past image brought into the present in order to 'complete' it is not simply a 'less violent' form of representation: it is rather the end of representation itself. And with the end of representation comes the beginning of a new ethical paradigm which Agamben will formulate as being beyond any 'resemblance' sought within the field of representation. This is a movement straight toward the pure word spoken not as a form of representation, but as a pure presentation, something Agamben refers to as an 'exposure', the true target of what any citation attempts to embody, but is ultimately

\footnotetext{
${ }^{3}$ These comments are to be read in conjunction with both Benjamin's and Agamben's work on Carl Schmitt and the notion of sovereignty implied therein, for it is only the decision of the sovereign as such that can cut through the aporia of authority, through its ungroundedness and its inability to justify its own existence (cf Schmitt, p. 5ff; Agamben 2005 b p. 1ff).

${ }^{4}$ Just such a proposal seems inherent in the work of Jacques Derrida who took up similar themes to these found here in his numerous works. See the conclusions drawn in Lawlor.
} 
incapable of doing. It is also the reason that Christianity, in his eyes, has elevated the very existence of language to the level of a sacrament (see Agamben 2010a).

Taking up these remarks on the attempt to present something beyond its representational confines alongside his writings elsewhere on the nature of the 'face', we are confronted with a unique understanding of citations as an attempt made within language to present the pure communicability of the human being — our face (Agamben 2000b, p. 97). There is a 'visage' beyond any representation that the reality of a particular face presents us with and that exposes us to the other before us, in all its nudity so to speak. Almost as if beyond this, there is also a fundamental linguistic element contained within such an exposure of our being - that which unites such an exposure of our visage with the nature of language and citations. As he puts it, 'The face is not something that transcends the visage: it is the exposition of the visage in all its nudity, it is a victory over character - it is word' (Agamben 2000b, p. 97). It is a word of pure expression seemingly beyond all language and yet which invokes a particular experience of language (much as citations often seek to do).

In other words, the face $i s$ language itself, the pure word that humanity has been searching for and longing to cite in contestation of an unjust (authoritarian) sovereign rule of representations within the present. This is the radical insight that Agamben seems to be pointing us toward, and that which would certainly give us pause to (re)consider how it is that we write and record ourselves in language. It is moreover what we have apparently been searching for within history and what Benjamin's 'dialectical materialism' sought to retrieve from the ruins of civilization. It is the summit of that which all character points toward and which must courageously be presented in its 'nudity' before another face (cf. the emphasis on nudity in Agamben 2010b). It is what Agamben will refer to as the quasi-mystical, quasisacred 'exposition' of the face as it becomes the truth presented beyond representations, beyond the limitations constitutive of the human being as a particular, historical construct. Over and beyond this, its exposition is also the pure showing of the face that language is unable to present in linguistic terms. The face can only present this reality by exposing itself, by showing itself as it were. Ultimately, Agamben's complete revisioning of ethics results, as we shall see, in this attempt to comprehend the face as the present-image that is dialectically, materially sought in fulfillment of the past, the face of the other before us, and the real quotation which Benjamin longed to cite.

\section{Conclusion}

It was Michel de Certeau who once quipped that it was the art of citation which '[...] appears to be the ultimate weapon for making people believe' (de Certeau, p. 188). This was the case for him 
because citation could be said to play off people's assumptions concerning belief. Our 'reality' is generated by our reliance upon the general sense of belief which circulates around us through the (self)citations continuously being performed in society. Citation, in fact, for de Certeau, provides a modern sense of credibility in the face of religious disintegration and thus comes to replace those unbelievable doctrines that once were seen to support the religious (or perhaps all representational) life.

For Agamben, being beyond representation means being beyond citation, and beyond the varied notions of sovereignty associated with it, hence beyond the historical forms of religious life tout court. In truth, the face is what citations ultimately strive to become, to embody as it were, like the 'whatever' nature of the infant's face, searching for something wholly beyond authority and that usually comes to define a relation of love (Agamben 1993c, p. 106ff). The face is the citation sought among the ruins of history that can yet give life to the fractured human self and which can provide the much sought after sense of 'transcendence in immanence' that religions have subsequently distorted and monopolized. Hence the appropriation of citationality by a gender-theorist such as Judith Butler is not as remote from this context as it might seem at first glance. It is this stress upon the body called forward through language into history that she is seeking to recover and to love, in all its embodiable forms, a celebration of a 'whatever' being that demands to be loved as much as addressed, not subjected to a series of violent (normative) representational frameworks which strive for hegemonic bids of sovereign power (Butler 2004; cf. Agamben 1993c, p. 20ff).

Agamben's development of Benjamin's theory of citationality yields a hope that human nature can get beyond cultural significations in some sense, beyond political representations and enter into an unforeseen world, not utopian, but rather the most realistic one could imagine. In what might be the simplest clarification on what paradise could in fact be: ' $[\ldots]$ here language [...] returns to that which never was and to that which it never left, and thus it takes the simple form of a habit' (Agamben 1991, p. 97). This would be a bold move toward a new form of writing, one that strives to be a habit more than a sovereign claim to power. Just what such a form of writing might entail, however, remains an open question, one very much needing to be further explored.

\section{Notes}

1. 'Since the goal is already present and thus no path exists that could lead there, only the perennially late stubbornness of a messenger whose message is nothing other than the task of transmission can give back to man, who has lost his ability to appropriate his historical space, the concrete space of his action and knowledge' (Agamben 1999, p. 114). 
2. Likewise, this seems to be the source of Agamben's involvement with German legal theorist Carl Schmitt and his Homo Sacer project, for the link between citation and authority is one which reveals the powers at work in our world as much as the means toward subverting them (cf. Agamben 1998; Agamben 2005b).

3. These comments are to be read in conjunction with both Benjamin's and Agamben's work on Carl Schmitt and the notion of sovereignty implied therein, for it is only the decision of the sovereign as such that can cut through the aporia of authority, through its ungroundedness and its inability to justify its own existence (cf Schmitt, p. 5ff; Agamben 2005b p. 1ff).

4. Just such a proposal seems inherent in the work of Jacques Derrida who took up similar themes to these found here in his numerous works. See the conclusions drawn in Lawlor.

\section{References}

Agamben, G. (1991) Language and Death: The Place of Negativity (trans. K. E. Pinkus and M. Hardt, Minneapolis, MN, University of Minnesota Press).

Agamben, G. (1993a) Infancy and History (trans. L. Heron, London, Verso).

Agamben, G. (1993b) Stanzas: Word and Phantasm in Western Culture (trans. R. L. Martinez, Minneapolis, MN, University of Minnesota Press).

Agamben, G. (1993c) The Coming Community (trans. M. Hardt, Minneapolis, MN, University of Minnesota Press).

Agamben, G. (1998) Homo Sacer: Sovereign Power and Bare Life (trans. D. Heller-Roazen, Stanford, Stanford University Press).

Agamben, G. (1999) The Man without Content (trans. G. Albert, Stanford, Stanford University Press).

Agamben, G. (2000a) Potentialities: Collected Essays (ed. D. Heller-Roazen, Stanford, Stanford University Press).

Agamben, G. (2000b) Means without Ends: Notes on Politics (trans. V. Binetti and C. Casarino, Minneapolis, MN, University of Minnesota Press).

Agamben, G. (2004) The Open: Man and Animal (trans. K. Attell, Stanford, Stanford University Press). 
Agamben, G. (2005a) The Time that Remains: A Commentary on the Letter to the Romans (trans. P. Dailey, Stanford, Stanford University Press).

Agamben, G. (2005b) State of Exception (trans. K. Attell, Chicago, University of Chicago Press).

Agamben, G. (2007) Profanations (trans. J. Fort, New York, Zone).

Agamben, G. (2010a) The Sacrament of Language: An Archaeology of the Oath (trans. A. Kotsko, Stanford, Stanford University Press).

Agamben, G. (2010b) Nudities (trans. D. Kishik and S. Pedatella, Stanford, Stanford University Press).

Benjamin, W. (1973) Letter to Gerhard Scholem, 12 June 1938 in G. Scholem and T. Adorno, (eds.), Briefe (Frankfur a.M., Fischer).

Benjamin, W. (1999a) Selected Writings, vol. 2, part 2 (eds. H. Eiland and M. W. Jennings, trans. E. Jephcott et al., Cambridge, MA, Belknap).

Benjamin, W. (1999b) The Arcades Project (trans. H. Eiland and K. McLaughlin, Cambridge, MA, Belknap).

Benjamin, W. (2002) Selected Writings, vol. 3 (eds. H. Eiland and M. W. Jennings, trans. E. Jephcott et al., Cambridge, MA, Belknap).

Benjamin, W. (2003) Selected Writings, vol. 4 (eds. H. Eiland and M. W. Jennings, trans. E. Jephcott et al, Cambridge, MA, Belknap).

Butler, J. (1993) Bodies that Matter: On the Discursive Limits of “Sex” (London, Routledge).

Butler, J. (2004) Undoing Gender (London, Routledge).

Caygill, H. (1998) Walter Benjamin: The Colour of Experience (London, Routledge). 
Certeau, M. de (1984) The Practice of Everyday Life (trans. S. Rendall, Berkeley, CA, University of California Press).

Derrida, J. (1982) 'Signature Event Context' in Margins of Philosophy (trans. A. Bass, Chicago, University of Chicago Press).

Durantaye, L. de la (2009) Giorgio Agamben: A Critical Introduction (Stanford, Stanford University Press0.

Fritsch, M. (2005)The Promise of Memory: History and Politics in Marx, Benjamin, and Derrida (Albany, NY, State University of New York Press).

Lawlor, L. (2007) This Is Not Sufficient: An Essay on Animality and Human Nature in Derrida (New York, Columbia University Press).

Mills, C. (2009) The Philosophy of Agamben (Montreal, McGill-Queen's University Press).

Schmitt, C. (2005) Political Theology: Four Chapters on the Concept of Sovereignty (trans. G. Schwab, Chicago, University of Chicago Press)

Weber, S. (2008) Benjamin's-abilities (Cambridge, MA, Harvard University Press).

Zartaloudis, T. (2010) Giorgio Agamben: The Idea of Justice and the Uses of Legal Criticism (London, Routledge). 